Tomcsix, J. \& Guex-Holzer, S. (1954). J. gen. Microbiol. 10, 317-324

\title{
A Specific Cell-wall Reaction in Bacillus sp.
}

\author{
By J. TOMCSIK AND S. GUEX-HOLZER \\ Institute for Hygiene and Bacteriology, University of Basle, Switzerland
}

SUMMARY: The cell wall of a bacillus, related to Bacillus anthracis, reacts specifically with the homologous antibody. This reaction can be made clearly visible by phase contrast when cell wall and cytoplasmic membrane are separated by mild lysozyme digestion, or when the cytoplasm is partially autolysed or digested with trypsin. The same antibody reacts with the transverse septa and polar bodies of the capsule, rendering them visible by phase contrast. These septa are in continuation of the cross walls of the cell, and sometimes give the appearance of division.

By these means the morphological locations of the chemically isolable fractions of serologically active bacterial extracts can be defined. These substances in the cell wall and in the septa and polar bodies of the capsule appear to be polysaccharide. The D-glutamic acid polypeptide element of the capsule does not occur in the cell wall.

A non-specific cell-wall reaction can be obtained with proteins at the appropriate values of pH, analogous to the non-specific capsular reaction previously reported.

Few observations have been made upon the visible effects of antibody on the bacterial cell wall. An increase in electron opacity and a decrease in clarity of outline of Salmonella typhi and Bacillus subtilis, after reaction with homologous antibody, was observed by Mudd \& Anderson (1941). We have ourselves observed that non-capsulated bacteria appeared to increase in thickness, as seen by the phase-contrast microscope, after reaction with the homologous serum, which may be due to a precipitation of antibody on the cell-wall surface. We have shown that a morphologically and chemically complex structure can be demonstrated by these means in the capsule of $\boldsymbol{B}$. megaterium and the related Bacillus M ('Tomesik, 1950, 1951; Tomesik \& Guex-Holzer, 1951). Whereas with anthrax D-glutamic polypeptide antibody a homogeneous capsular material was made visible by phase contrast, the appearance with homologous antibodies revealed conspicuous septa and polar bodies, apparently polysaccharide in nature.

After various degrees of lysozyme digestion of both living and heat-killed capsulated bacteria, the surface structures were demonstrated by the homologous antibodies (Tomcsik \& Guex-Holzer, 1952), and it can be shown that at the appropriate stage of the reaction the cell wall and cross walls are rendered clearly visible to phase contrast by the same polysaccharide antibody which reacts with the septa and polar structures of the capsule.

This specific cell-wall reaction is not visible in intact cells, but can be shown in material in which the cytoplasm has been autolysed or digested with trypsin.

It may be argued that the specificity of this reaction is compromised by the use of digested bacteria; lysozyme will eventually destroy the cell wall completely (Welshimer \& Robinow, 1949). Similarly, the final appearance of cells which have undergone this reaction might, because of the dilatation of the cell wall, be confused with the so-called 'capsular swelling reaction', which is 
discussed below. One purpose of this paper is, therefore, to indicate the occurrence of the specific cell-wall reaction under a wider variety of conditions, in both capsulated and non-capsulated bacteria.

\section{MATERIALS}

The strain Bacillus M, isolated and described by us (Tomesik, 1950; Tomcsik \& Guex-Holzer, 1951), was used in preference to typical strains of B. megaterium because of its stable production of mucoid colonies for 4 years on Gladstone \& Fildes (1940) CCY agar, and because of the constant appearance in its capsule of the polypeptide-polysaccharide complex structure, even without added glucose in the medium. The non-capsulated form could regularly be obtained by culturing it in Gladstone \& Fildes bouillon or Sauton medium, aerated by negative pressure in litre suction flasks, each containing $300 \mathrm{ml}$., with cottonwool stoppered glass tubes extending below the surface of the medium.

D-Glutamic acid polypeptide antibody was produced in rabbits by ten to fourteen injections with suspensions of $B$. anthracis, grown on agar in $20 \%$ $(\mathrm{v} / \mathrm{v}) \mathrm{CO}_{2}$, and killed by heating at $100^{\circ}$ for $30 \mathrm{~min}$.

The homologous serum, which did not contain polypeptide antibody, and will be designated the polysaccharide antibody, was prepared by immunizing two groups of rabbits with eight to ten doses of capsulated and of noncapsulated washed suspension of Bacillus $M$ respectively, at intervals of 3 days.

\section{METHODS}

One drop of bacterial suspension was permitted to dry briefly on a cover slip, to cause the organisms to adhere, and a further drop of water was added to replace the evaporation. The cover slip was inverted on a slide and a loopful of undiluted serum was placed on the edge, so that it was drawn in by capillary action. By this means the majority of bacteria remained undisturbed by the currents created and it was possible to make serial photomicrographs of the same field before and after successive applications of sera. The capsular reaction was conducted, except where otherwise stated, with $24 \mathrm{hr}$. cultures of living bacteria; longer incubation or preliminary treatment, in the form of a 'microdissection' with trypsin or lysozyme or by autolysis, in order to destroy the cytoplasm, or at least to separate the cell wall from the cytoplasmic membrane, as described below, was necessary in order to demonstrate the specific cell-wall reaction. Photomicrographs were made as described by Tomesik \& Guex-Holzer (1953).

\section{RESULTS}

Untreated bacilli. The $24 \mathrm{hr}$. cultures showed mucoid colonies with capsulated bacilli of the 'rough' type (Bisset, 1948), usually with four cells but sometimes less or considerably more. Normally the capsule is invisible by phase contrast (Pl. 1, fig. 1), but when the polypeptide antibody is added a homogeneous capsule becomes visible in bacilli grown on agar; the bright, non-reactive zone between cell and capsule corresponds to the cell wall (Pl. 1, fig. 2). Whenever it proved possible to add polysaccharide antibody without disturbing the bacilli under the microscope which had already reacted with the polypeptide 
antibody, the following changes were observed (Pl. 1, fig. 3). Distinct septa appeared across the capsule, sometimes appearing to split into two layers on the convex side of curved chains; dark polar structures appeared, corresponding to the apparent depressions at the poles which could sometimes be observed with the polypeptide antibody alone; and in place of the previous homogeneous appearance of the capsule, a striated structure could be observed.

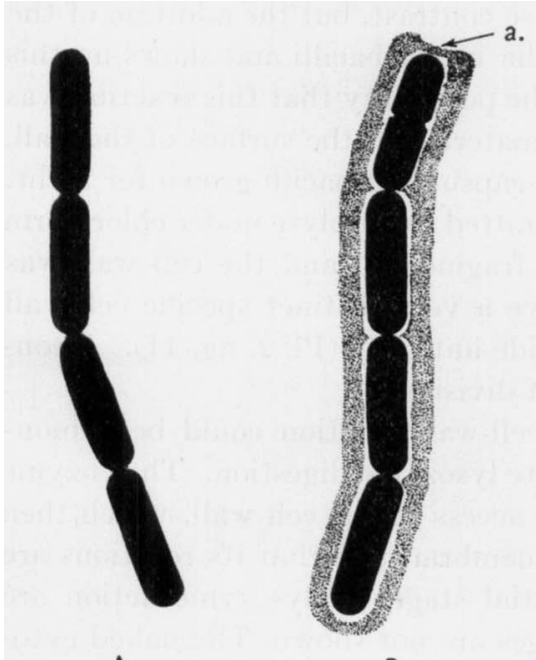

A
B

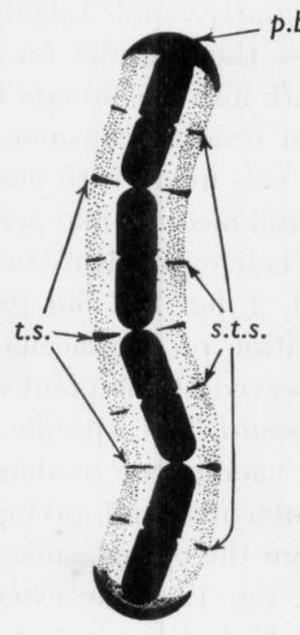

C

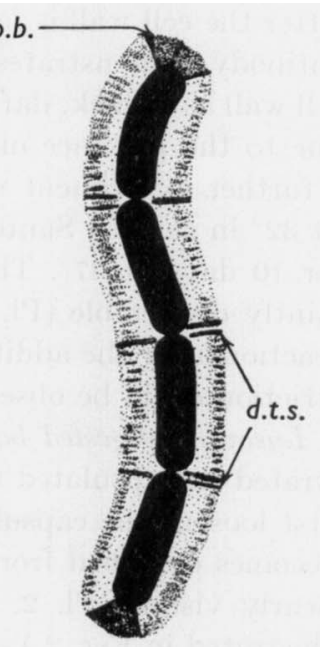

D

Fig. 1. A: Bacillus M by phase contrast without immune serum. B: the same bacillus after the addition of polypeptide antibody; $a=$ polar depression. C: addition of homologous immune serum; t.s.=transverse septa; s.t.s. = secondary transverse septa (at the site of incomplete cell divisions); $p . b .=$ polar body. D: the same as $\mathrm{C}$ in curved chain; d.t.s.= divided transverse septa.

These appearances were independent of the age of the culture, but a modified and very striking reaction was obtained if the growth from a $3 \mathrm{hr}$. aerated Sauton bouillon culture at $32^{\circ}$ was centrifuged, and a small amount of sediment resuspended in saline. An initial marked motility was inhibited by homologous serum diluted up to 1:1200, indicating the presence of flagellar antibodies, but neither polypeptide nor polysaccharide antibody was capable of demonstrating any capsular material at this stage. If, however, the sediment was kept at room temperature, in the dark, for 3 days, the secondary growth showed loss of motility, with chain formation and very large capsules, which reacted to the antibodies with the production of very thick septa, extending across the chain and projecting beyond it at the edges (Pl. 1, fig. 4). On the convex sides of curved chains the double structure of these thick septa could clearly be seen (Pl. 1, fig. 6). The polar, polysaccharide structures were voluminous (PI. I, fig. 4), and, even with the polypeptide antibody alone, a striated appearance could be discerned (Pl. 1, figs. 5, 7), with gaps corresponding to the polysaccharide septa. It is only reasonable to assume that the entire striated structure of the polypeptide capsule is complementary to the striated polysaccharide described above. In Fig. 1 A-D we summarize schematically the most typical capsular reactions. 
Autolysed bacilli. After incubation in CCY agar at $32^{\circ}$ for some days, occasional bacilli showed disintegration of the cytoplasm, but only rarely of the capsule. Spore formation was not seen, but could be induced, in some individuals, on a medium containing potato extract. Pl. 2, figs. 8, 9, show such a culture before and after the addition of polysaccharide antibody. Several intact bacilli and a short chain with two spores can be seen. In the latter the cell wall is faintly visible by phase contrast, but the addition of the antibody demonstrates the capsules on the intact bacilli and shows up this cell wall as a thick, dark line. To obviate the possibility that this reaction was due to the presence of residual capsular material on the surface of the wall, a further experiment was made with non-capsulated bacilli grown for $\mathbf{2 4} \mathrm{hr}$. at $32^{\circ}$ in aerated Sauton medium and permitted to autolyse under chloroform for 10 days at $37^{\circ}$. Their cytoplasm was fragmented and the cell wall was faintly discernible (Pl. 2, fig. 10), but gave a very distinct specific cell-wall reaction after the addition of polysaccharide antibody (Pl. 2, fig. 11). A constriction could be observed at the point of division.

Lysozyme-digested bacilli. The specific cell-wall reaction could be demonstrated on capsulated bacilli after moderate lysozyme digestion. The enzyme first loosens the capsular material, giving access to the cell wall, which then becomes detached from the cytoplasmic membrane, so that its reactions are clearly visible (Pl. 2, fig. 12). The essential stages of lysozyme action are illustrated in Fig. 2A-D, but the last stages are not shown. The naked cytoplasts may survive after dissolution of the wall; their contents go slowly into solution and finally the empty, spherical membrane also disappears. These changes occur in a similar manner when boiled bacilli are used, so that it appears improbable that autolytic enzymes play an important part in the major stages of the reaction. The coagulated cytoplasts, fixed in a rod shape, do not similarly dissolve, however, and at this stage autolytic enzymes may take part in the dissolution of normal bacilli.

Without the addition of the polysaccharide antibody, the cell walls of lysozyme-digested bacilli are only faintly visible ( $\mathrm{Pl}$. 2, fig. 13); but with antibody the cell wall and cross walls are clearly seen at an advanced stage of digestion. We consider that this observation makes it improbable that any simulation of a specific cell-wall reaction might be caused by the adherence to the wall of residual capsular substances.

Trypsin-digested bacilli. Trypsin digestion of both capsulated and noncapsulated bacilli was performed by adding $50 \mathrm{mg}$. (approx.) commercial trypsin (Siegfried, Zofingen) with chloroform to $10 \mathrm{ml}$. of saline suspension of bacteria, adjusted to $\mathrm{pH} 8$ and incubated at $37^{\circ}$ for $6-24 \mathrm{hr}$.

Under phase contrast, after addition of the polysaccharide antibody, the cell wall and capsule appeared almost intact; the latter somewhat shrunken (Pl. 3, fig. 16). The polar structures were very obvious; the cell wall appeared as a dark line, and the cross walls and capsular septa showed as a series of straight lines across the chain, alternatively thicker and thinner, along its length. This appearance strengthened our conviction that these capsular septa represented true cell divisions, of which the thinner examples were presumably the less 
mature. Digestion was most apparent within the cell wall, where all that remained was a small, sharply defined rod-like or spherical body, usually one per cell, and exhibiting marked Brownian movement. We cannot venture to speculate upon the identity of this body.

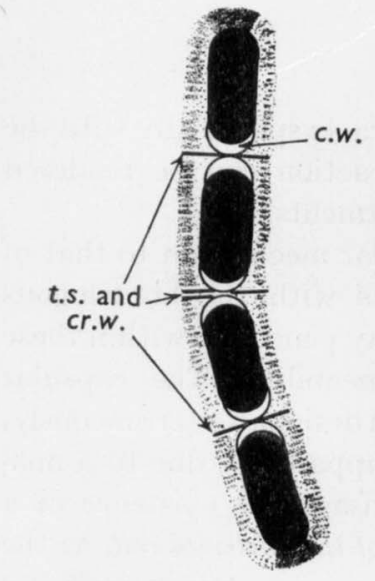

A

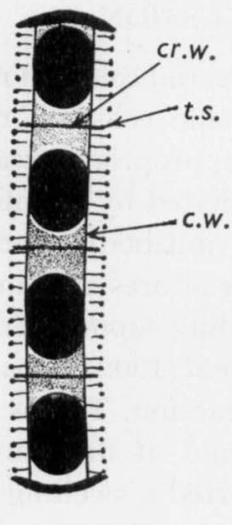

B

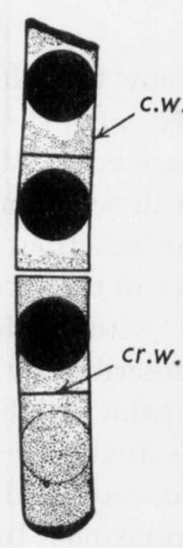

C

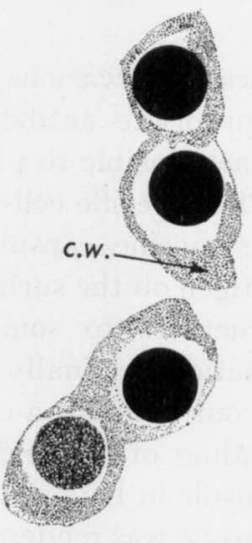

D

Fig. 2. Demonstration of the cell wall with homologous immune serum on lysozyme-treated bacilli. $\mathrm{A}-\mathrm{D}=$ successive stages of lysozyme digestion; $c . z v .=$ cell wall; $c r . w .=$ cross wall; $t . s .=$ transverse septum. A: dilatation of the cell wall and initial stage of spherical transformation of the cytoplasm. A gradual disintegration of the capsule and the release of polypeptide and polysaccharide substances begins. $B$ : the capsule is partially disintegrated; the cell wall and the cross wall also react with the polysaccharide antibody. The transverse capsular septa are thinner, but not yet totally disintegrated; they form a direct continuation of the cross walls. The spherical transformation continues in parallel with the further dilatation of the cell wall. $C$ : the capsular structure, including the transverse septa, disappears entirely; the cell wall and the cross walls do not appear to be adversely affected and they react strongly with antibody. The cell wall at the end of the chains is thicker. The cross walls may show a double structure. The spherical transformation of the cytoplasm is complete; some of the spherical bodies may lose their original dark appearance. D: the chains are disarticulated. First the cross walls, then the cell walls disintegrate; they still react, however, with antibody before their final dissolution.

Shrinkage of the capsule after trypsin digestion was most apparent in the secondary growth forms of the originally non-capsulated bacilli from aerated Sauton medium (compare Pl. 1, fig. 4, Pl. 3, fig. 17), in which changes in the rigidity of the cell wall could also be seen (Pl. 3, fig. 17). These bacilli gave no cell-wall reaction with polypeptide antibody (Pl. 3, fig. 18), and no structure was revealed in the capsule by reaction at an inter-isoelectric $\mathrm{pH}$ with bovine plasma albumin (Tomesik \& Guex-Holzer, 1954), although a secondary swelling of the capsule occurred (Pl. 3, fig. 19). It was repeatedly observed that the residual globular bodies reacted at acid $\mathrm{pH}$ values; their size was considerably increased and their Brownian movement ceased entirely.

The non-capsulated bacteria reacted as was anticipated when digested with trypsin. Before the addition of serum the cell wall appeared as a thin line (Pl. 3, fig. 20). It reacted strongly with polysaccharide antibody and gave a 
non-specific reaction with proteins at acid $\mathrm{pH}$ values (Pl. 3, figs. 21, 22). The reaction of the small bodies with proteins at acid $\mathrm{pH}$ values was very marked (PI. 3, fig. 22). The specific wall reaction, before and after the addition of polysaccharide antibody, was also observed in the same chain of trypsindigested, non-capsulated bacilli (Pl. 3, figs. 23, 24).

\section{DISCUSSION}

These observations show that the bacterial cell wall reacts specifically with the appropriate antibody, and this specific cell-wall reaction can be rendered clearly visible to phase contrast by appropriate treatments.

The specific cell-wall reaction is elicited by a similar mechanism to that of the specific capsular reaction. The antibody reacts with the homologous antigen on the surface of these cell structures, and may penetrate within these structures to some extent, depending upon permeability. The capsular reaction, originally described by Neufeld (1902), is still designated (erroneously, in our opinion) a capsule swelling reaction. This is apparently due to a misreading of Neufeld's text. He did not at first envisage the existence of a capsule in his pneumococci and reported a swelling of the bacterial cell, as the capsule was rendered visible. In fact the main reaction is an antigen-antibody precipitation, causing changes in refractility; secondary capsular swelling occurs only occasionally in certain types of bacteria, and the non-specific capsular reaction, depending upon protein precipitation within the capsular substance at inter-isoelectric pH (Tomcsik \& Guex-Holzer, 1953, 1954) leads more frequently to shrinkage.

If the principle underlying both specific cell-wall and capsular reaction is the same, and if a particular antibody reacts equally well with the cell wall and with the transverse septa of the capsule, then it appears that the same substances must take part in the formation of both. Our previous studies (Tomcsik \& Guex-Holzer, 1951, 1952) indicate that this particular antibody reacts with polysaccharides, but it remains to be proved, by the absorption of the serum with purified bacterial extracts, that a single substance is concerned. We hope to be able to report soon upon our immunochemical studies on the identity of this material in the cell wall and capsular septa, but the present work eliminates the possibility that D-glutamic acid takes part in these structures.

Apart from these similarities, the close relationship between the capsular septa and the cellular cross walls is indicated by our morphological observations. The latter structures designated 'cross walls' (Knaysi, 1951) or 'transverse cell walls' (Bisset, 1948, 1950) do not stain well with basic dyes, and the term septum is more frequently used to describe a transverse growth of the basophilic cytoplasmic membrane, preceding division. By our methods we could not distinguish septum and wall in this sense, and although our capsular structures had no affinity for dyes, we use the term septum because of its more general connotations.

The question of whether complex structures can be produced by and upon the cell wall, we now consider to have been answered in the affirmative. But 
whether the cytoplasmic membrane takes part in this production, and what is the relationship of these polysaccharide structures to the cell wall, we do not yet know.

This investigation was aided by a grant from the Rockefeller Foundation. Our thanks are due to Dr K. A. Bisset for revising the text and to Miss A. Beckmann for technical assistance.

\section{REFERENCES}

Bisset, K. A. (1948). The cytology of smooth and rough variation in bacteria. J. gen. Microbiol. $2,83$.

Bisset, K. A. (1950). The Cytology and Life-history of Bacteria. Edinburgh: E. and S. Livingstone, Ltd.

Gladstone, G. P. \& Fildes, P. (1940). A simple culture medium for general use without meat extract or peptone. Brit. J. exp. Path. $21,161$.

KNaYsi, G. (1951). Elements of Bacterial Cytology. 2nd ed. Ithaca, N.Y.: Comstock.

Mudd, S. \& Anderson, T. F. (1941). Demonstration by the electron microscope of the combination of antibodies with flagellar and somatic antigens. J. Immunol. $42,251$.

Neufeld, F. (1902). Über die Agglutination der Pneumokokken und über die Theorien der Agglutination. Z. Hyg. InfectKr. 40, 54.

Tomcsik, J. (1950). Ửber eine bewegliche Mutante des Bacillus anthracis. Schrweiz. Z. allg. Path. 13, 616.

Tомсsiк, J. (1951). Complex structure of the bacterial capsule in the genus Bacillus. Experientia, 7, 459.

Tomcsix, J. \& Guex-Holzer, S. (1951). Anthrax-Polpeptid und andere speziesspezifische Substanzen der Kapsel in der Bazillus-Gruppe. Schweiz. Z. allg. Path. $14,515$.

Tomcsik, J. \& Guex-Holzer, S. (1952). Änderung der Struktur der Bakterienzelle im Verlauf der Lysozym-Einwirkung. Schweiz. Z. allg. Path. 15, 518.

Tomcsik, J. \& Guex-Holzer, S. (1953). Ein neues Prinzip zur Färbung der Bakterienkapsel. Schweiz. Z. allg. Path. 16, 882.

Tomcsik, J. \& Guex-Holzer, S. (1954). Demonstration of the bacterial capsule by means of a pH-dependent, salt-like combination with proteins. J. gen. Microbiol. 10, 97.

Welshimer, H. J. \& Robinow, C. F. (1949). The lysis of Bacillus megatherium by lysozyme. J. Bact. 57, 489 .

\section{EXPLANATION OF PLATES}

Bacillus $\mathbf{M}$ by phase-contrast microscopy. All plates at $\times 2500$.

Prate 1

Fig. 1. Capsulated bacteria; no antibody.

Fig. 2. Capsulated bacteria; polypeptide antibody.

Fig. 3. Capsulated bacteria; first polypeptide, afterwards polysaccharide antibody (the same microscopic field as in fig. 2).

Fig. 4. Originally non-capsulated bacteria from aerated Sauton culture; secondary capsule production in the centrifuged sediment at room temperature in 3 days. Polysaccharide antibody. Note the exceptionally thick transverse septa.

Fig. 5. Bacteria as in fig. 4. Polypeptide antibody. The distribution of the secondarily produced polypeptide is not homogeneous. Gaps in place of the polysaccharide transverse septa.

Fig. 6. Bacteria as in fig. 4. Polysaccharide antibody. Swollen bacteria. In a few places, at the convex side of the curved chains, split transverse capsular septa.

Fig. 7. Bacteria as in fig. 4. Polypeptide antibody. Exceptionally inhomogeneous distribution of polypeptide material. Larger gaps in place of the polysaccharide transverse capsular septa. 
Plate 2

Fig. 8. Four-day old potato-agar culture. In the majority capsulated bacteria. No anti body. Spores in one chain.

Fig. 9. The same microscopic field as in fig. 8. Polysaccharide antibody. Specific cell-wall reaction on the sporulating chain and specific capsular reaction on the other bacteria.

Fig. 10. Non-capsulated bacteria from aerated Sauton culture, autolysed. No antibody; the cell wall is barely visible.

Fig. 11. The same bacterium as in fig. 10. Polysaccharide antibody. The cell wall appears as a thick line.

Fig. 12. Capsulated bacteria digested with 1:100 egg white for $10 \mathrm{~min}$. at room temperature. Polysaccharide antibody. Cell-wall and cross-wall reaction. Capsular structure partially detached. The remnants of capsular transverse septa are located at the prolongation of the cross walls. The spherical transformation of the cytoplasm is complete.

Fig. 13. Non-capsulated bacteria from aerated CCY (Gladstone \& Fildes) bouillon, partially digested with lysozyme. No antibody. The cell wall is barely visible. The spherical transformation of the cytoplasm is not yet complete.

Fig. 14. Bacteria prepared as in fig. 13. Polysaccharide antibody. Cell-wall and cross-wall reaction. Spherical transformation of the cytoplasm is further advanced.

Fig. 15. Similar preparation to fig. 14. The specific cell-wall reaction is pronounced. In one place unusual spherical deformation of the cell wall.

\section{Plate 3}

Fig. 16. Capsulated bacteria digested with trypsin. Polysaccharide antibody. Specific cellwall and capsular reaction. Note the trypsin-resistant cytoplasmic bodies.

Fig. 17. Similar preparation to fig. 16. Polysaccharide antibody. The trypsin digestion is more pronounced.

Fig. 18. The same bacterial suspension as in fig. 17. Polypeptide antibody. No cell-wall reaction, no capsular structure.

Fig. 19. Originally non-capsulated bacteria from aerated Sauton culture; secondary capsule production in the centrifuged sediment at room temperature in 3 days. Trypsin digestion. No antibody. Non-specific capsular reaction with bovine plasma albumin Fr. V; buffer pH 2.6. Enlargement and immobilization of the cytoplasmic bodies, not digested with trypsin.

Fig. 20. Non-capsulated bacteria from aerated Sauton bouillon, digested with trypsin. No antibody. The cell wall can be discerned as a very thin line.

Fig. 21. Bacteria as in fig. 20. Polysaccharide antibody. Specific cell-wall reaction.

Fig. 22. Bacteria as in fig. 20. No antibody. Non-specific cell-wall reaction with bovine plasma albumin Fr. V; buffer pH 2. Enlargement and immobilization of the trypsinresistant cytoplasmic bodies.

Fig. 23. Bacteria as in fig. 20. No antibody. The cell wall can hardly be discerned.

Fig. 24. The same field as in fig. 23. Polysaccharide antibody. Very clear specific cell-wall reaction.

(Received 5 October 1953) 
Journal of General Microbiology, Vol. 10, No. 2
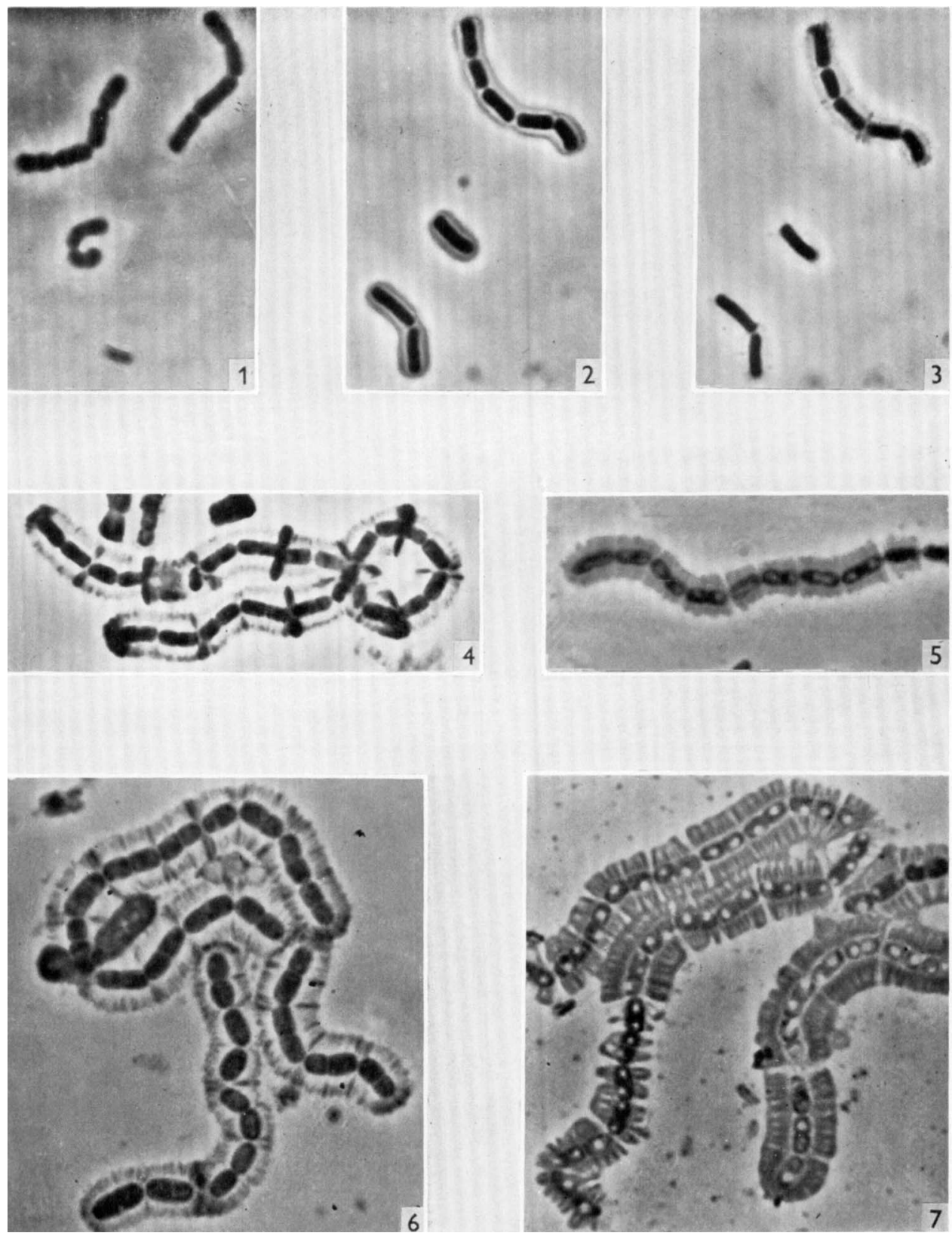

J. 'Tomcsik \& S. Guex-Holzer-A cell-wall reaction. Plate 1 
Journal of General Microbiology, Vol. 10, No. 2
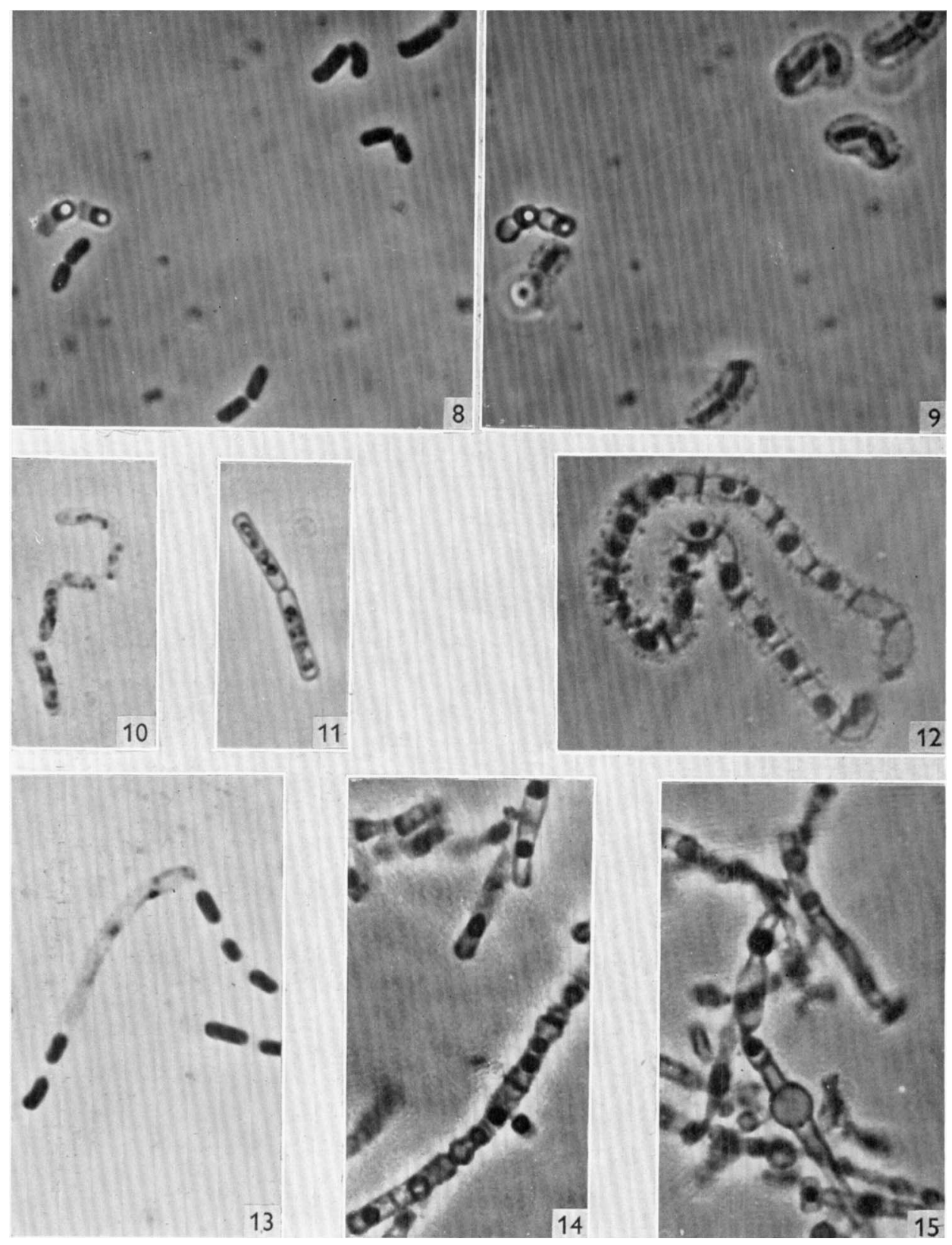

J. Tomcsik \& S. Guex-Holzer-A cell-wall reaction. Plate 2 
Journal of General Microbiology, Vol. 10, No. 2
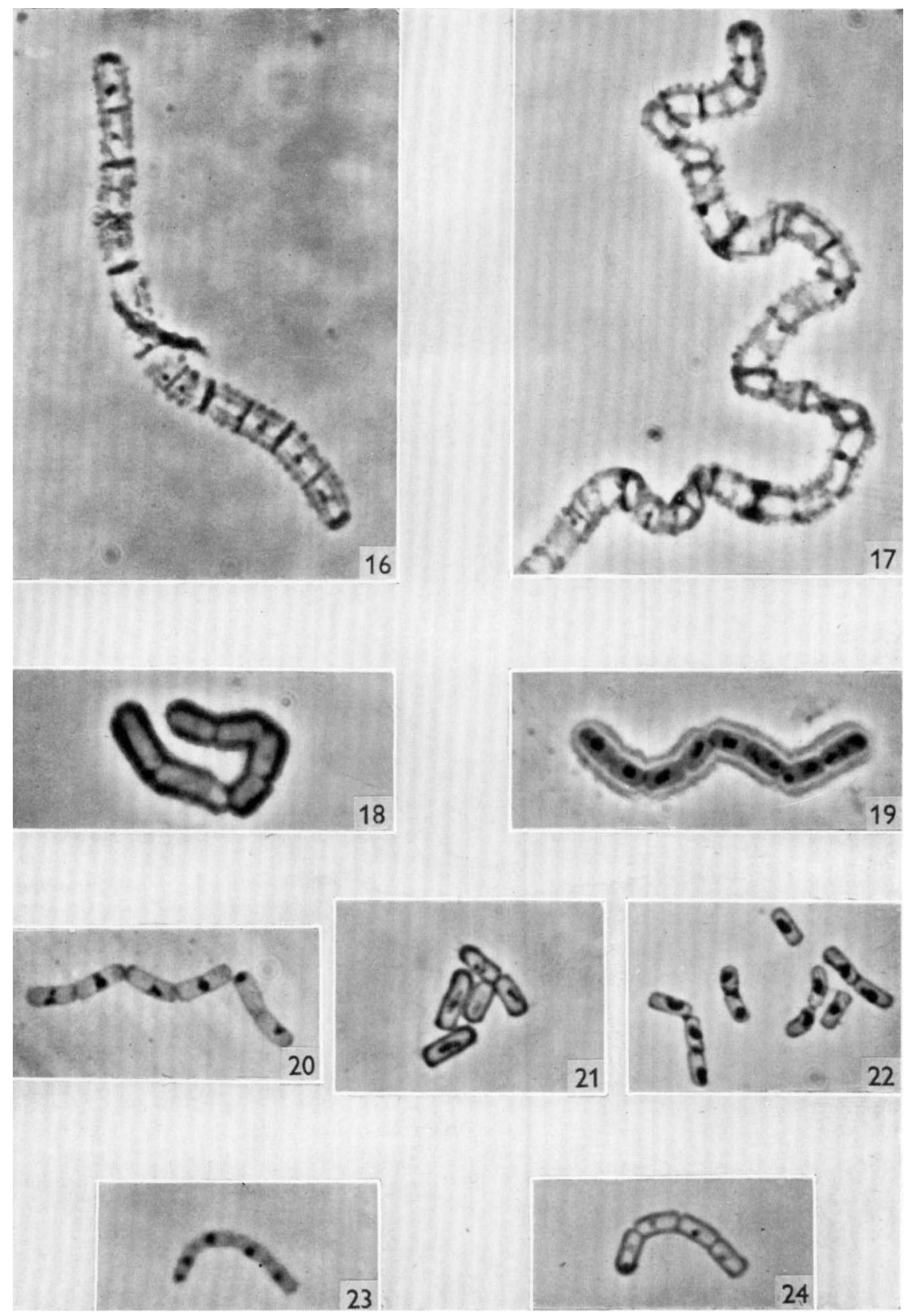

J. 'Tomcsik \& S. Guex-Holzf R-A cell-wall reaction. Plate 3 